\title{
THE ICONOCLASM ON MODERN KNOWLEDGE SYSTEM REGIME IN BOB DYLAN'S “ONE MORE CUP OF COFFEE (TO THE VALLEY BELOW”): A NARRATOLOGY AND DECONSTRUCTIVE STUDY”
}

\author{
Imam Hendra Saputra \\ STIKIP PGRI Banjarmasin \\ imam.hendra.s@mail.ugm.ac.id
}

\begin{abstract}
The bestowal of Nobel Prize 2016 in Literature for having created new poetic expressions within the great American song tradition to Bob Dylan indicated that the understanding of literature in postmodern world has begun to permeate its traditional boundary of definition. The research will deploy textual analysis approach with the focus to narratology, with conclusion base on deductive analysis on the holistic data relation. The data collecting method initiates mostly with close reading. Subsequently, those data are divided, arrange and grouped to certain criteria that support the process of analysis. Dylan's "One More Cup of Coffee (To the Valley Below") uniquely identifies the conventional knowledge as something that is not ultimate, instead it identifies it as something that has the value of truth which may be rivaled by other kind of system of truth. The plural existence of system of knowledge is not only acknowledge as juxtaposed entities, but even furthermore deconstructed to be something that successfully find the true essence of truth does not found in conventional system of knowledge.
\end{abstract}

Keywords: Nobel Prize, Bob Dylan, iconoclasm, music, deconstruction

\section{INTRODUCTION}

The bestowal of Nobel Prize 2016 in Literature for having created new poetic expressions within the great American song tradition to Bob Dylan indicated that the understanding of literature in postmodern world has begun to permeate its traditional boundary of definition. The value of literature, to be specifically poetry, has now been recognized to be presented in the music world as well as in the traditional genre of literature. Thus, an epiphany brought upon the possibility of the criticism upon the cross traditional form of literature such as toward songs or movies, or maybe even other form such as journalism text or the form of expression that involve the present of textual narration.

Subsequently, Dylan's works are very interesting to be understood as the epitome of how the music world finally achieve the recognition of the 
literature world. The existence of his work need to be scrutinized further to understand of how the work become phenomenally influencing the literature world as the award suggested. The mechanism of his work undisputedly has its share on whatever value on subversively put the classic understanding of the world of literature aside from the great melodious ballad of his songs. The rebellious nature carried by the lyrics move the listeners' spirit to be more critical in facing everyday reality.

The inspiring nature of the music does not battle alone, instead it is magnified by the powerful poetic lyric in contains. The music acts as the real-life soundtrack, ushers their cause with the beat just like a trumpet of war that maintain the spirit of the soldiers to keep marching forward. The provocative spirit such as in Dylan's songs are really needed by the society to bring more moral support for their critical act on the phenomena of life. This power that the lyrics brings is very interesting to be analyzed in literary paradigm, due to its poetic nature which has already confirmed by the Nobel Prize award it has received in 2016.

Among Dylan's songs, “One More Cup of Coffee (To the Valley Below") portrait how scientific knowledge is eclipsed by the mysterious nature of exotic prowess. While "The Times They are A-Changin"” on the other hand, is holding the explicit nature of rebellion against the status quo, "One More Cup of Coffee (To the Valley Below") acts subtler within the dictions. Hence, it is interesting to decipher how the narrative works to promote the rebellious spirit while maintaining the appearance of the diction subtle instead of as conspicuous as the one found in other Dylan's work "The Times They are AChangin."'

The research will deploy textual analysis approach with the focus to narratology, with conclusion base on deductive analysis on the holistic data relation. At the first phase of the analysis. The main data source for the research is Dylan's “One More Cup of Coffee (To the Valley Below") 
and "The Times They are A-Changin."'. Other data source, such as supporting data taken from related literatures are only complimentary.

The data collecting method initiates mostly with close reading, during the time the literary work which in this case is Dylan's "One More Cup of Coffee (To the Valley Below") and "The Times They are A-Changin.'" is carefully and thoroughly read and the important lexical units are identified according to its relation to the research questions. Subsequently, those data are divided, arrange and grouped to certain criteria that support the process of analysis.

Another method to complete additional data information is run online and offline. Weather online or offline searching data is having the aim to provide additional necessary data for the research, such as related research, expert opinion and so on. Offline, the additional data collecting method would be exercised through visiting various necessary relevant place such as library or expert place. Online, would be involving browsing to several sites - either paid or free which has included the related data to the research. Later on, those collected data are arranged, grouped and catalogued base on its relevant for further analysis.

To accompany the structural analysis and deductive approach on the research, I draw tables, which consist of data taken from the text within Dylan's “One More Cup of Coffee (To the Valley Below") and "The Times They are A-Changin."'. Later on, the data is classified base on logical arrangement. The already systematically grouped data are analyzed one by one. Each potential syntactical and semantical structures are analyzed to harvest the deep meaning of the units. Later on, the collection of analysis results is further analyzed it relation among them to get the details and total picture of the value of the story and narrative of the work. After finding the details and total, the next phase is to relate the finding contextually to the research question. Upon the later stage of the analysis, hopefully, conclusion may be 
extracted and presented on the research.

\section{THEORY}

\section{NARRATOLOGY}

Narratology is a branch of literary science which mainly for formalism and structuralism school is very popular. For formalist and structuralist, the value of a literary work is on the literariness of the work as Chatman (17:1928) said "Formalists and structuralists argue that it is not the literary text itself that is the subject of poetics but rather-to use Roman Jakobson's phrase-its "literariness."”

This approach of analyzing literary works focuses on how narrative within the internal structure of a literary text operates. The elements of in a literary work is part of grand design that defines the whole value of the literariness of a work. From there a set of mapping structure can create a question of "What can we say about the way structures like narrative organize themselves?" (Chatman, 19: 1928)
2. NARRATIVE, DISCOURSE AND STORY

Narrative or text is the textual entity of literary works that carries out a story with discourse and story as its utilities. The narrative structure of a literary work determines its state of value.

Discourse is "the expression, the means by which the content is communicated." (Chatman 19: 1928). The expression performs in a set of structured arrangement in communicating its content.

While discourse is the expression, the story is the content of the expression. The story contains the actual information of the communication. The two of them as Chatman said (19: 1928): "In simple terms, the story is the what in a narrative that is depicted, discourse the how."

\section{DISCUSSION}

1. THE KNOWLEDGE

"Your loyalty is

not to me 


\section{But to the stars}

above"

The propensity of the appearance of the rivalry shown with the expression of "your loyalty is not to $m e^{\prime \prime}$, by saying the words, Dylan express the existence of split loyalty to other than himself. Despite the inexplicit mentioning that credits to the empirical system of knowledge, the expression showing different object of loyalty is vivid phenomenon, that the other trust does not always solely obliged to or similar to that destined to self.

The appearance of negation "not" brings the strong negative attitude of defiance toward the self. Furthermore, with the "not" offer the chance for the binary opposition which bring upon the later "stars above" which may be identify to the traditional believe in the mystical system of knowledge of astrology that closely related to the gypsy's believe system. The empirical believe that put the truth as something that can be measure and neglect the location of the system has now been challenge by something that considered as irrational, and position - which is an absolute above in the sky - is now holding a crucial role for the believe eclipsing the phenomena itself. The stars also betray the spirit in empirical system that uphold the potentiality to be acquired by everybody that willing to try to understand it. Positioned "above" in the sky, the stars are out of reach for the ordinary people, which it makes the knowledge of the stars may only be acquired be the exclusive few. The time of the appearance of the stars itself - although astrology does not always have to be practiced in the night time - can only be seen during the night, which is an opposition to the spirit of renaissance, the illumination that gives clarity toward the darkness which shroud a mystery.

\section{Your daddy he's}

an outlaw

\section{And a wanderer}

by trade

"An outlaw" indicate the present of rebellious class who live on the other side of the system, the only 
law that should be ruling the civilization. The presence of "an outlaw" means that the law does not hold everything absolutely, the grip of the power has Achilles' heel that let the chances for rebellion, which means it possible for the - empirical - law to be somehow flaw, and legitimate the birth of "an outlaw". As "an outlaw", the base of knowledge that the "outlaw" gains are by becoming " $a$ wanderer", who is likely found the knowledge by experience. This ballad put the "wanderer" to be the advocate of the alternative knowledge, who live the life as a person who becomes the living prove of a knowledge does not necessarily always gain from the conventional academic course.

\section{He'll teach you \\ how to pick and choose \\ And how to \\ throw the blade}

Subsequently, the already "outlaw" person distribute the alternative form of knowledge through the unordinary system of knowledge distribution. The substances of knowledge are also something that is not commonly introduce in formal academic life. "pick and choose" and "throw the blade" are definitely not something that anybody can learn in the ordinary school. When a pupil sit in the class, the pupil would normally learn from lecture and textual book about scientific system of knowledge, yet in these lyrics, the pupil learns about "how to pick and choose" something. The presence of "something" here is syntactically necessary to be existed in the sentence although it is not explicitly stated in the lyric, since without it the sentence would be incomplete. Moreover, something in here is the object target of the verb "pick and choose", which indicate it as the noun of the sentence, which later can be found in next line as "the blade." However, further information about "something" may be gathered by the deduction of how the learning process is acquired and distributed.

As it said before, the knowledge, either the substance or the 
method of distribution is somewhat uncommon for the regime of system of knowledge, that means "the blade" here behaves as the weapon which has the power to battle against the regime of authority. "The blade" as a kind of weapon has to also be understood as a small concealable weapon which can be used effectively against the larger and more modern weapon such as sword, spear, and gun. As a smaller weapon, however inferior as it may seem, "the blade" has certain advantage when it is used as sudden close quarter combat, or as a thrown weapon as it is taught in the lyric when the wanderer teaches "how to throw the blade". On the other side, the weapon has poor perk when it is used as melee weapon in medium or long range. From the characteristic of "the blade" above, it is clear - when it is understood as the rebellious weapon against the authority - how the method of rebellion is deploy, it is subtle, graceful because of the person who use it need to have proficient skill to handle it against more larger weapon, and has strong mobility.
He oversees his

kingdom

So no stranger

does intrude

Albeit the nature of the wanderer who teach the knowledge to others, the wanderer also act as the guardian of the mysterious knowledge. "His kingdom" which is the stronghold with the knowledge inside it, is "overseen" personally by him, guarantee that it is in the best security without the trust to someone else other than him. This attitude is contradictive with the nature of modern system of knowledge which are giving as largest as possible the chance for everybody to learn the knowledge, and the trust for someone else perception since the argument always can be checked for its validity through the open standardized empirical system of knowledge.

The barrage from the outside world intrusion later be reinforced by the statement"no stranger does intrude." Learning without permission is impossible for this kind of knowledge, and since the teacher 
figure here is the "father," the nature of how the knowledge is as a legacy among the descendants. Anybody else, outside the family tree is considered as a threat, and will not be allowed to enter "his kingdom". By claiming that the "kingdom" is his, under his own supervision, and he is the father who recognize anybody else as stranger, it means that he is the absolute authority of the knowledge system, which put the mainstream regime of knowledge to be not only rivalled but also binarily oppositioned.

Dylan's “One More Cup of Coffee

(To the Valley Below") uniquely identifies the conventional knowledge as something that is not absolute, instead it identifies it as phenomena of plurality. The diction disrupts the already stable system of knowledge and display the offer of an alternative view of the world.

$$
\begin{array}{r}
\text { Your sister sees } \\
\text { the future } \\
\text { Like your mama } \\
\text { and yourself }
\end{array}
$$

When the constellation of the family tree is observed, it is clear that the unordinary system of knowledge is integral to the family value. "Your sister sees the future like your mama and yourself" put the mother, sibling and "you" in the same characteristic box of knowledge to whom the father introduces the knowledge. How the family "sees the future" is also bind the whole family into a pack that share the same ideology of how to see the world is running.

$$
\begin{array}{r}
\text { You've never } \\
\text { learned to read } \\
\text { or write } \\
\text { There's no } \\
\text { books upon your } \\
\text { shelf }
\end{array}
$$

Thus, the "shelf" which has no book in it is also belong to the small exclusive community. The system of how the knowledge is acquired which is without the process of "read or write" - is also shared among them. From this, and to be related to the fatherly figure who has become the source of knowledge - despite the fact 
that it means that the whole family is belong solely to the father - it then can further be concluded that the family becomes the important "kingdom" where the knowledge is flourished within. For the sake of the continuity of the system, the family need to be observe in close watch, and that is why the reason of the father as the owner of the "kingdom" to not to put the trust the guard to somebody else is make sense.

The vivid statement of the absence of book portrays the firm defiance against the empirical system of knowledge. The "shelf" which is ordinarily in the educated family is filled with books, here is definitely not filled with books. The contain of the shelf itself does not matter, what matter is the negation of "no books upon your shelf" which has a strong message of how ordinary source of knowledge has little or even no meaning in the tabula rasa of family.

\section{And your \\ pleasure knows \\ no limits}

\author{
Your voice is \\ like a \\ meadowlark \\ But your heart \\ is like an ocean \\ Mysterious and \\ dark.
}

Those exclusive nature, either of the family or the knowledge, makes the whole thing mysterious as it is said in "mysterious and dark." Despite the "mysterious and dark" characteristic of the knowledge and the family, "your voice is like meadowlark", an imagery that indicate the exquisite nature of someone's voice despite you in here is not formally educated. "Your voice" here has to be also understood further not just as someone physical voice but also as the perk of someone to express the ideology against the world, which is normally the value of someone with higher formal education.

The you in here is also portrayed as someone who possess the beautiful value of freedom as "your pleasure knows no limit" despite the close nature of the kingdom, with which everything is owned by the 
father, a clear rival against the democracy value with usually intact to the modern empiric science. The mainstream deduction of happiness comes from freedom, and freedom comes from democracy does not occurs in here, instead the family find the "pleasure knows no limits", the "voice" of a "meadowlark", and the depth of "an ocean" are built above the foundation that is very much different with the system that is recognized by the majority as the main and only method of gaining knowledge.

One more cup of coffee for the road

One more cup of coffee 'fore I go.

To the valley below.

Later, the I here, put himself as the outsider, which is indicated by the statement that he has to go "to the valley below", and ask for coffee. The decision to go and for coffee make him as the merely a guest for the mysterious family, as someone who is kept at bay that will never be allowed to "intrude". The portrayal of a stranger for the $\mathrm{I}$ is furthermore put below by mentioning that the place that he has to go into is "the valley below" the current mysterious family "kingdom" occupy. The hierarchical structure then is reversed, the stranger who belong to the mainstream world of system of knowledge is put down, under the supremacy of the marginal community. The suppression does not stop there, the I is also asking for coffee to the marginal family, to give the I support to face "the valley below". The coffee as it is made by the marginal family, should be recognized to have the potential of having a spill of the "mysterious" and "pleasure" of the forbidden knowledge.

\section{CONCLUSION}

Dylan's “One More Cup of Coffee (To the Valley Below") uniquely identifies the conventional knowledge as something that is not ultimate, instead it identifies it as something that has the value of truth which may be rivaled by other kind of system of 
truth. The plural existence of system of knowledge is not only acknowledge as juxtaposed entities, but even furthermore deconstructed to be something that successfully find the true essence of truth does not found in conventional system of knowledge. It is also worth to notice that the freedom that for the modern society may only be found through formal education that bring light into illuminating the darkness, here instead may also be offered through the non-modern approach of a system of knowledge that in modern society normally considered as the ignorant values. Thus, it brings the iconoclasm against the stability of the current regime, and re-introduce the possibility of other way that the society may previously reject as the way to reach the truth of life.

\section{REFERENCES}

Adi, Ida Rochani. 1993. Fiksi Populer: Teori dan Metode Kajian. Yogyakarta: Pustaka Pelajar
Barry, Peter. 2010. Beginning Theory (terj. Harfiyah Widiawati dan Evi Setyarini). Yogyakarta: Jalasutra

Bressler, Charles E. 1998. Literary Criticism: An Introduction to Theory and Practice. New Jersey: Prentice Hall

Eagleton, Terry. 2010. Teori Sastra: Sebuah Pengantar Komprehensif (terj. Harfiyah Widiawati dan Evi Setyarini). Yogyakarta: Jalasutra

Junus, Umar. 1986. Sosiologi Sastra Persoalan Teori dan Metode. Kuala Lumpur: Dewan Bahasa dan Pustaka Kementrian Pelajaran Malaysia

Kipling, Rudyard. 2004. The Jungle Books. Delhi: Rohan Book Company

Makaryk, Irena Rima. 1995. Encyclopedia of Contemporary Literary Theory: Approaches, Scholars, Terms. London: 


$\begin{array}{lrrr}\text { University of Toronto Press } & \text { Moore-Gilbert, } & \text { Bart. } & 1997 . \\ \text { Incorporated } & \text { Postcolonial Theory Contexts, } \\ & \text { Practices, Politics. London: Verso }\end{array}$

Mc Leod, John. 2000. Beginning Postcolonialism. Manchester: Newton, K. M. 1997. TwentiethManchester University Press Century Literary Theory. London: Macmillan Press Ltd 


\section{APPENDIX}

\section{One More Cup of Coffee (To the Valley Below)}

Your breath is sweet

Your eyes are like two jewels in the

sky

Your back is straight your hair is

smooth

On the pillow where you lie

But I don't sense affection

No gratitude or love

Your loyalty is not to me

But to the stars above

One more cup of coffee for the road

One more cup of coffee 'fore I go.

To the valley below.

Your daddy he's an outlaw

And a wanderer by trade

He'll teach you how to pick and choose

And how to throw the blade

He oversees his kingdom
So no stranger does intrude

His voice it trembles as he calls out

For another plate of food.

One more cup of coffee for the road One more cup of coffee 'fore I go.

To the valley below.

Your sister sees the future

Like your mama and yourself

You've never learned to read or write

There's no books upon your shelf

And your pleasure knows no limits

Your voice is like a meadowlark

But your heart is like an ocean

Mysterious and dark.

One more cup of coffee for the road

One more cup of coffee 'fore I go.

To the valley below. 


\section{The Times They Are A-Changin'}

Come gather around people

Wherever you roam

And admit that the waters

Around you have grown

And accept it that soon

You'll be drenched to the bone

And if your breath to you is worth saving

Then you better start swimming or

you'll sink like a stone

For the times they are a-changing

Come writers and critics

Who prophesize with your pen

And keep your eyes wide

The chance won't come again

And don't speak too soon

For the wheel's still in spin

And there's no telling who that it's

naming

For the loser now will be later to win

Cause the times they are a-changing

Come senators, congressmen

Please heed the call

Don't stand in the doorway

Don't block up the hall
For he that gets hurt

Will be he who has stalled

There's the battle outside raging

It'll soon shake your windows and rattle your walls

For the times they are a-changing

Come mothers and fathers

Throughout the land

And don't criticize

What you can't understand

Your sons and your daughters

Are beyond your command

Your old road is rapidly aging

Please get out of the new one if you can't lend your hand

Cause the times they are a-changing

The line it is drawn The curse it is cast The slowest now Will later be fast As the present now Will later be past

The order is rapidly fading And the first one now will later be last Cause the times they are a-changing 